\title{
GROWTH AND MINERAL NUTRITION IN SEEDLINGS OF JACARANDÁ-DA-BAHIA SUBJECTED TO NUTRIENT DEPRIVATION
}

\author{
Leandro Carlos ${ }^{1}$, Nelson Venturin ${ }^{2}$, Elias de Sá Farias², Regis Pereira Venturin ${ }^{3}$, \\ Renato Luiz Grisi Macedo ${ }^{2}$ \\ ${ }^{1}$ Instituto Federal Goiano, Rio Verde, Goiás, Brasil - lcmaestro@gmail.com \\ ${ }^{2}$ Federal University of Lavras, Department of Forest Sciences, Lavras, Minas Gerais, Brasil - venturin@dcf.ufla.br; \\ elias_ef_ufla@yahoo.com.br; rlgrisi@dcf.ufla.br \\ ${ }^{3}$ Empresa de Pesquisa Agropecuária de Minas Gerais, Belo Horizonte, Minas Gerais, Brasil - regis@epamig.br
}

Received for publication: 12/11/2013 - Accepted for publication: 11/09/2014

\begin{abstract}
With the objective of evaluating the nutritional requirements and the effects of nutrient deprivation in developing of Jacarandá da Bahia seedlings (Dalbergia nigra (Vellozo) Freire Allemao ex Bentham), a greenhouse experiment was conducted. The experiment had fully randomized design, with 12 treatments and 8 replications. The following treatments were applied: Complete 1 (C1-fertilized with $\mathrm{N}, \mathrm{P}, \mathrm{K}, \mathrm{S}, \mathrm{B}, \mathrm{Cu}, \mathrm{Zn}$ and liming as $\mathrm{Ca}$ and $\mathrm{Mg}$ sources), complete 2 (Complete 1 - liming with $\mathrm{CaSO}_{4} \cdot 2 \mathrm{H}_{2} \mathrm{O}$ and $\mathrm{MgSO}_{4} \cdot 7 \mathrm{H}_{2} \mathrm{O}$ as $\mathrm{Ca}$ and $\mathrm{Mg}$ sources), C1-N, C1-P, C1-K, C1-S, C1-B, C1-Zn, C1liming, $\mathrm{C} 2-\mathrm{Ca}, \mathrm{C} 2-\mathrm{Mg}$ and control. Diameter and height were measured and plants were separated into aerial part and root system. Samples were dried, weighed and levels of nutrients in the aerial dry matter were measured. Phosphorus was the most growth limiting factor, the sequence of nutritional requirements presented by Jacarandá da Bahia seedlings in relation to the complete treatment was: $\mathrm{P}$ $>\mathrm{Ca}>\mathrm{B}>\mathrm{K}>\mathrm{S}>\mathrm{Zn}>\mathrm{Mg}>\mathrm{N}$.

Keywords: Missing element; Dalbergia nigra; rainforest; hardwood.
\end{abstract}

\section{Resumo}

Crescimento e nutrição mineral de mudas de jacarandá-da-bahia sob efeito da omissão de nutrientes. Com o objetivo de avaliar exigências nutricionais e os efeitos da omissão de nutrientes no desenvolvimento de mudas de Jacarandá da Bahia (Dalbergia nigra (Vellozo) Freire Allemao ex Bentham), conduziu-se um experimento com o uso da técnica de elemento faltante. Foram empregados 12 tratamentos, em um delineamento inteiramente casualizado com oito repetições. Adotaram-se os seguintes tratamentos: Completo 1 (adubado com N, P, K, S, B, Cu, Zn e calagem como fonte de $\mathrm{Ca}$ e $\mathrm{Mg}$ e corrigindo acidez do solo), completo 2 (completo 1 - calagem tendo $\mathrm{CaSO}_{4} \cdot 2 \mathrm{H}_{2} \mathrm{O}$ e $\mathrm{MgSO}_{4} \cdot 7 \mathrm{H}_{2} \mathrm{O}$ como fontes de $\mathrm{Ca}$ e $\mathrm{Mg}$ sem corrigir acidez do solo), C1-N, C1-P, C1$\mathrm{K}, \mathrm{C} 1-\mathrm{S}, \mathrm{C} 1-\mathrm{B}, \mathrm{C} 1-\mathrm{Zn}, \mathrm{C} 1$-calagem, C2-Ca, C2-Mg e testemunha. Foram medidos diâmetro e altura das plantas e separadas em parte aérea e sistema radicular. As mudas foram secas, pesadas e foram determinados os teores de nutrientes na matéria seca da parte aérea. O fósforo foi o nutriente mais limitante ao crescimento de jacarandá da Bahia; a sequência de exigência nutricional apresentada pelas mudas de Jacarandá da Bahia em relação ao tratamento completo em ordem decrescente foi: $\mathrm{P}$ > $\mathrm{Ca}>\mathrm{B}>\mathrm{K}>\mathrm{S}>\mathrm{Zn}>\mathrm{Mg}>\mathrm{N}$.

Palavras-chave: Elemento faltante; Dalbergia nigra; Mata Atlântica; madeira nobre.

\section{INTRODUCTION}

The Atlantic Forest, which contains great biodiversity, is considered one of the most important biomes in the world. However, it is known as one of the most threatened ones, being considered a conservation hotspot, due to the high degree of endemism and imminent extinction dangers (MYERS $e t$ al., 2000). 
The species Dalbergia nigra suffered intense exploitation in the past and appears in the list of endangered species of the Brazilian Institute of Environment and Renewable Natural Resources (IBAMA, 1992), thus, extraction is now forbidden, being allowed only plantation and later harvesting. Due to this reason, it is extremely important to create technologies in order to determine silvicultural practices for this species.

Several studies highlighted the importance of fertilization in native forest species as one of the aspects involved with productivity and quality improvements, and in success when establishing forest plantations. A fast and safe tool in forest fertilization and nutrition programs is making experiments in vase (PRITCHETT, 1979).

A fast and economic way to perform studies on nutritional requirements is the lacking nutrient technique, to make a qualitative assessment of a nutrient in soil. This technique consists in assessing the development of a species in greenhouse or in field, using a complete treatment (with all the necessary nutrients in not limiting or toxic doses) and a series of treatments where one nutrient at a time is not available to the plant. It is a simple and safe technique to identify nutritional deficiencies. To avoid a result influenced by deficiencies of other nutrients, sources of all the other nutrients are added to the treatment, in not toxic nor limiting doses (BRAGA et al., 1995).

According to Chaminade (1972), the lacking nutrient technique shows which are the nutrients with low availability, the relative importance of this deficiency and velocity of soil fertility reduction. According to Malavolta (1980), it shows a semi-quantitative reference of the fertilizing necessity.

Scientific studies on nutritional necessities of Jacaranda-da Bahia are at early stage. However, several studies have been conducted on nutritional requirements of forest species with wood production potential, like Quina (Myroxylon peruiferum L.F.), Australian red cedar (Toona ciliata M. Roem var. australis) and cedar (Cedrela fissilis Vell.) (CARLOS et al., 2013, MORETTI et al., 2011, SOUZA et al., 2009).

Dalbergia nigra (Vellozo) Freire Allemao ex Bentham, commonly known as Jacarandá-daBahia, Jacarandá-Preto or Caviúna, is a tree species of the Fabaceae family, found in the Atlantic Forest region of San Paolo, passing by Minas Gerais, Rio de Janeiro, Espirito Santo until reaching Bahia. The species is 40 to $80 \mathrm{~cm}$ in diameter, has irregular and crooked trunk, height between 15 and $25 \mathrm{~m}$. Its wood is moderately heavy, with density around $0.87 \mathrm{~g} \mathrm{~cm}^{-3}$, very strong, with long natural durability and quite decorative. It is known worldwide, used for various applications, like luxury furniture, internal finish in civil construction, machined parts and musical instruments mainly in construction of pianofortes, among others (LORENZI, 2002; CARVALHO, 1994; RIBEIRO et al., 2011).

Considering the little knowledge on nutritional requirements of Jacarandá-da-Bahia, this work had the objective to assess the nutritional condition and the effect of nutrient retirements on growth of seedlings of the species.

\section{MATERIAL AND METHODS}

This study was conducted in the greenhouse of the Forest Sciences Department in the Federal University of Lavras (UFLA). Red Latosol was used as substrate, with low natural fertility, collected in a field close to Lavras, MG, at 0.20 to $0.40 \mathrm{~m}$ depth. Material from the fertile layer was discarded not to influence the effects of the fertilizers used.

Soil was dried out and sieved, with $10 \mathrm{~mm}$ mesh size sieve and then $4.5 \mathrm{dm}^{3}$ of soil were put into vases with $4.8 \mathrm{dm}^{3}$ capacity. In the aftermath, liming was performed, according to the designed treatments. During this process, limestone was homogenized with soil.

Starting from this point, water was added and soil humidity was maintained around $60 \%$ of the Total Pore Volume (TPV), according to the methodology described by Freire et al. (1979) and verified daily by weighing, reaching the correct weight by adding deionized water.

Limestone was left for twenty days in incubation to let it react with soil. After this incubation period, the other nutrient sources were added according to the designed treatments. Twelve treatments were tested in a completely randomized experimental design, with eight replications, being each replication represented by a vase with a plant (Table 1 ). 
Table 1. Identification and characterization of treatments.

Tabela 1. Identificação e caracterização dos tratamentos.

\begin{tabular}{lc}
\hline Treatment & Characterization \\
\hline Complete $1(\mathrm{C} 1)$ & Application of $\mathrm{N}, \mathrm{P}, \mathrm{K}, \mathrm{S}, \mathrm{B}, \mathrm{Cu}, \mathrm{Zn}+$ limestone \\
Complete $2(\mathrm{C} 2)$ & Comp 1 - limestone $+\mathrm{CaSO}_{4} \cdot 2 \mathrm{H}_{2} \mathrm{O}$ and $\mathrm{MgSO}_{4} \cdot 7 \mathrm{H}_{2} \mathrm{O}$ \\
$\mathrm{C} 1-\mathrm{Cal}$ & Complete 1 except limestone \\
$\mathrm{C} 1-\mathrm{N}$ & Complete 1 except $\mathrm{N}$ \\
$\mathrm{C} 1-\mathrm{P}$ & Complete 1 except $\mathrm{P}$ \\
$\mathrm{C} 1-\mathrm{K}$ & Complete 1 except $\mathrm{K}$ \\
$\mathrm{C} 1-\mathrm{S}$ & Complete 1 except S \\
$\mathrm{C} 1-\mathrm{B}$ & Complete 1 except B \\
$\mathrm{C} 1-\mathrm{Zn}$ & Complete 1 except $\mathrm{Zn}$ \\
$\mathrm{C} 2-\mathrm{Ca}$ & Complete 2 except $\mathrm{Ca}$ \\
$\mathrm{C} 2-\mathrm{Mg}$ & Complete 2 except $\mathrm{Mg}$ \\
$\mathrm{C}$-ntrol & Natural soil \\
\hline
\end{tabular}

For treatments with limestone, doses were calculated adopting the method of increasing base saturation (V) at 60\%, according with the formula proposed by Raij (1981). The corrective factor used was calcined dolomite limestone, micro pulverized, with $36 \%$ of $\mathrm{CaO}, 14 \% \mathrm{Mg}$ ) (PRNT equal to $100 \%$ ). In the $\mathrm{C} 2$ treatment, $\mathrm{Ca}$ and $\mathrm{Mg}$ were supplied in form of $\mathrm{CaSO}_{4} \cdot 2 \mathrm{H}_{2} \mathrm{O}$ and $\mathrm{MgSO}_{4} \cdot 7 \mathrm{H}_{2} \mathrm{O}$, with the only scope to supply $\mathrm{Ca}$ and $\mathrm{Mg}$ without changing the other characteristics of soil.

Doses of sources for treatments were calculated, when pertinent, meeting the basic fertilizing requirements $\left(\mathrm{mg} \mathrm{dm}^{3}\right)$, according to Malavolta, (1980), Alvarez, (1974), Passos, (1994) and Marques et al. (2006): 180 of N, 300 of P, 150 of K, 150 of Ca, 50 of $\mathrm{Mg}, 40$ of S, 1.33 of $\mathrm{Cu}, 0.81$ of B and 4 of $\mathrm{Zn}$. The following salts p.a. were used as sources: $\mathrm{Ca}\left(\mathrm{HPO}_{4}\right)_{2} \mathrm{H}_{2} \mathrm{O}, \mathrm{KH}_{2} \mathrm{PO}_{4}, \mathrm{KNO}_{3}, \mathrm{KCl}, \mathrm{NH}_{4} \mathrm{NO}_{3}$, $\left(\mathrm{NH}_{2}\right) 2 \mathrm{CO}, \mathrm{MgSO}_{4} 7 \mathrm{H}_{2} \mathrm{O}, \mathrm{K}_{2} \mathrm{SO}_{4}, \mathrm{NH}_{4} \mathrm{H}_{2} \mathrm{PO}_{4}, \mathrm{H}_{3} \mathrm{PO}_{4}, \mathrm{Mg}\left(\mathrm{NO}_{3}\right)_{2} 6 \mathrm{H}_{2} \mathrm{O},\left(\mathrm{NH}_{4}\right)_{2} \mathrm{SO}_{4}, \mathrm{CaSO}_{4} 2 \mathrm{H}_{2} \mathrm{O}$, $\mathrm{H}_{3} \mathrm{BO}_{3}, \mathrm{CuCl}_{2}, \mathrm{ZnCl}_{2}$. Nitrogen and Potassium, when applied, were divided into 3 doses, first at planting, one after 30 days and the last after 60 days.

Table 2. Chemical and physical components of the natural soil and after fertilization with macro and micronutrients to Jacarandá-da-Bahia. in greenhouse in Lavras, MG.

Tabela 2. Componentes físicos e químicos do solo natural e após adubação com macro e micronutrientes para Jacarandá-da-Bahia em casa de vegetação em Lavras, MG.

\begin{tabular}{|c|c|c|}
\hline Atttributes & Natural soil & After complete fertilization \\
\hline $\mathrm{pH}\left(\mathrm{H}_{2} \mathrm{O}\right)$ & 4.8 & 5.7 \\
\hline $\mathrm{P}\left(\mathrm{mg} / \mathrm{dm}^{3}\right)$ & 1.71 & 70.06 \\
\hline $\mathrm{K}\left(\mathrm{mg} / \mathrm{dm}^{3}\right)$ & 23 & 126 \\
\hline $\mathrm{Ca}^{2+}\left(\mathrm{cmol}_{\mathrm{c}} / \mathrm{dm}^{3}\right)$ & 0.4 & 1.9 \\
\hline $\mathrm{Mg}^{2+}\left(\mathrm{cmol}_{\mathrm{c}} / \mathrm{dm}^{3}\right)$ & 0.1 & 0.5 \\
\hline $\mathrm{Al}^{3+}\left(\mathrm{cmol}_{\mathrm{c}} / \mathrm{dm}^{3}\right)$ & 0 & 0 \\
\hline $\mathrm{H}+\mathrm{Al}\left(\mathrm{cmol}_{c} / \mathrm{dm}^{3}\right)$ & 5.05 & 4.04 \\
\hline $\mathrm{SB}\left(\mathrm{cmol}_{\mathrm{c}} / \mathrm{dm}^{3}\right)$ & 0.56 & 2.72 \\
\hline (t) $\left(\mathrm{cmol}_{\mathrm{c}} / \mathrm{dm}^{3}\right)$ & 0.56 & 2.72 \\
\hline (T) $\left(\mathrm{cmol}_{\mathrm{C}} / \mathrm{dm}^{3}\right)$ & 5.61 & 6.76 \\
\hline $\mathrm{V}(\%)$ & 9.98 & 40.23 \\
\hline $\mathrm{m}(\%)$ & 0 & 0 \\
\hline $\mathrm{MO}(\mathrm{dag} / \mathrm{kg})$ & 0.5 & 0.5 \\
\hline $\mathrm{Zn}\left(\mathrm{mg} / \mathrm{dm}^{3}\right)$ & 0.3 & 2.7 \\
\hline $\mathrm{Fe}\left(\mathrm{mg} / \mathrm{dm}^{3}\right)$ & 12.6 & 11.2 \\
\hline $\operatorname{Mn}\left(\mathrm{mg} / \mathrm{dm}^{3}\right)$ & 1.8 & 1 \\
\hline $\mathrm{Cu}\left(\mathrm{mg} / \mathrm{dm}^{3}\right)$ & 0.4 & 2.1 \\
\hline $\mathrm{B}\left(\mathrm{mg} / \mathrm{dm}^{3}\right)$ & 0.3 & 0.5 \\
\hline $\mathrm{S}\left(\mathrm{mg} / \mathrm{dm}^{3}\right)$ & 20.7 & 48.5 \\
\hline Areia (dag/kg) & 16 & 16 \\
\hline Silte (dag/kg) & 20 & 20 \\
\hline Argila (dag/kg) & 64 & 64 \\
\hline
\end{tabular}

FLORESTA, Curitiba, PR, v. 45, n. 1, p. 107 - 116, jan. / mar. 2015.

Carlos, L. et al.

ISSN eletrônico 1982-4688 / ISSN impresso 0015-3826 
With the objective to prove the effect of fertilization, an analysis of the natural soil was performed (control) together with the analysis of the complete treatment (C1) (Table 2). Texture was determined (Densimeter method) according to Brazilian Agricultural Research Corporation (Empresa Brasileira de Pesquisa Agropecuaria) (EMBRAPA, 1997). Chemical analyses were conducted by the following methods, $\mathrm{pH}\left(\mathrm{H}_{2} \mathrm{O}\right.$ - Relation 1:2.5); organic matter (Method of WALKELY; BLACK, 1934); $\mathrm{P}$ and $\mathrm{K}\left(\mathrm{HCl} \mathrm{0,05} \mathrm{mol} \mathrm{L}-1+\mathrm{H}_{2} \mathrm{SO}_{4} 0,025 \mathrm{~mol} \mathrm{~L}^{-1}\right.$ ), according to Vettori (1969); $\mathrm{Ca}, \mathrm{Mg}, \mathrm{Al}$ and $\mathrm{H}+\mathrm{Al}$ (KCl $1 \mathrm{~mol} \mathrm{~L}^{-1}$ extractor); $\mathrm{Zn}, \mathrm{Cu}, \mathrm{Fe}$ and $\mathrm{Mn}\left(\mathrm{HCl} 0,05 \mathrm{~mol} \mathrm{~L}^{-1}+\mathrm{H}_{2} \mathrm{SO}_{4} 0,25 \mathrm{~mol} \mathrm{~L}^{-1}\right)$ according to Viets Junior and Lindsay (1973); $\mathrm{S}\left(\mathrm{Ca}\left(\mathrm{H}_{2} \mathrm{PO}_{4}\right) . \mathrm{H}_{2}+500 \mathrm{ppm} \mathrm{P}\right)$, according to Tedesco et al. (1985); B (hot water) according to description by Jackson (1970). Analyses were conducted in the Laboratory od Soil Fertility in the Federal University of Lavras.

Dalbergia nigra seeds were collected in the Rio Doce State Park, MG. After sieving, they were pre-germinated in BOD germinators in the laboratory of forests seeds of DCF/UFLA, and as the rootlet protruded, seeds were transferred to vases with treatments.

The testing phase lasted six months. At the end, the experimental units were disassembled, roots were separated from soil by washing with running water, obtaining the complete and individualized seedlings. Diameter of neck (D) and height $(\mathrm{H})$ were measured; height was taken from ground level to the meristem of the apical gem of each plant.

Plants were separated into aerial part and root system, then taken to be dried in a forced air oven at $65{ }^{\circ} \mathrm{C}$, until reaching constant weight. Dry matters were weighed obtaining values for aerial part dry matter, root system dry matter and total dry matter.

Relative growth of diameter, height, dry matter of aerial part and dry matter of root system were calculated starting from collected data, using the formula:

$$
R G=\frac{N}{G 2} x 100
$$

where: RG: Relative growth of the calculated variable

$\mathrm{N}$ : Value of the variable in a given treatment

$\mathrm{G} 2$ : Value of the variable in the complete treatment 2.

With the values of height, diameter and with the dry weights of the root system, aerial part and total, the Dickson quality index (DQI) of seedlings was calculated (DICKSON et al., 1960), by the formula:

$$
D Q I=\frac{T D M}{\left(\frac{H}{D}\right)+\left(\frac{D M A P}{D M R S}\right)}
$$

where : DQI : Dickson quality index of seedlings,

TDM: Total dry matter $(\mathrm{g})$

H: Height of the plant at the apical gem $(\mathrm{cm})$

D: Diameter of root collar (mm)

DMAP: Dry matter of the aerial part $(\mathrm{g})$

DMRS: Dry matter of the root system $(\mathrm{g})$

Dry matter of the aerial part (stem, leaves and petioles) was grinded in a Willey mill and chemical analyses were conducted to determine total and accumulated contents of $\mathrm{N}, \mathrm{P}, \mathrm{K}, \mathrm{S}, \mathrm{Ca}, \mathrm{Mg}, \mathrm{B}$, $\mathrm{Cu}$ and ZN, according to Sarruge and Haag (1974). Analyses were made in the laboratory of plant mineral nutrition in the Department of Soil Sciences of UFLA. With data of nutrient contents, accumulation was obtained, being calculated by the formula.

$$
\text { Accumulation }(\mathrm{mg} / \mathrm{plant})=\text { Content }(\mathrm{g} / \mathrm{kg}) x D M A P(\mathrm{~g})
$$


Data were submitted to Shapiro-Wilk and Bartlett's tests, to verify the hypotheses of normality and homogeneity of variances. Once these hypotheses were confirmed, the test F-test was applied, through Analysis of Variance, and then the Scott-Knott test at 5\% of significance, to compare means between treatments (GOMES, 1985), using the program Sisvar4.6 (FERREIRA, 2011). Graphs and tables were obtained using Microsoft EXCEL 2010.

\section{RESULTS AND DISCUSSION}

\section{Plant growth}

Morphological characteristics like height, diameter and dry matter production, ratio root/aerial part and the Dickson Quality Index (DQI) are presented in table 3.

For diameter and height (Table 3 and Figure 1), omission of $\mathrm{P}, \mathrm{Ca}$ and control, resulted in lower values, showing that lack of these nutrients was a growth limiting factor in seedlings of Jacarandá-daBahia. $\mathrm{P}$ is an element with key role in all metabolites related to acquisition, storage and use of energy: phosphate sugars, phosphate adenosisns, nuceotids and nucleic acids, being therefore and essential element for genome and for acquisition of energy (EPSTEIN; BLOOM, 2004). Calcium is one of the most required elements during the vegetative phase of the plant than in the reproductive phase. It plays the structural roles of enzymatic regulator and secondary messenger; it is essential to maintain structural integrity of the cell wall and membranes, its lack causes membranes to allow dispersion of cytoplasm contents (MALAVOLTA, 2006).

Table 3. Height, diameter, dry mass of aerial part (DMAP), dry mass of root system (DMRS), total dry mass (TDM), relation root/aerial (R/PA) and Dickinson quality index (DQI) to seedlings of Jacarandá da Bahia in different treatments, 180 days after transplanting.

Tabela 3. Altura, diâmetro, matéria seca da parte aérea (DMAP), matéria seca do sistema radicular (DMRS), matéria seca total (TDM), relação raiz/parte aérea (R/PA) e Índice de Qualidade de Dickson (DQI) para mudas de Jacarandá da Bahia nos diferentes tratamentos, aos 180 dias após transplantio.

\begin{tabular}{|c|c|c|c|c|c|c|c|}
\hline Treatmets & Height & Diameter & DMAP & DMRS & TDM & $\mathbf{R} / \mathbf{P A}$ & DQI \\
\hline & $\mathbf{c m}$ & Mm & \multicolumn{5}{|c|}{ f................ g ................. } \\
\hline Test & $5.04 \mathrm{~d}$ & $1.72 \mathrm{~d}$ & $0.04 \mathrm{~d}$ & $0.08 \mathrm{~d}$ & $0.12 \mathrm{~d}$ & $2.07 \mathrm{a}$ & $0.035 \mathrm{c}$ \\
\hline C1-P & $16.34 \mathrm{c}$ & $1.85 \mathrm{~d}$ & $0.06 \mathrm{~d}$ & $0.10 \mathrm{~d}$ & $0.17 \mathrm{~d}$ & $1.82 \mathrm{a}$ & $0.018 \mathrm{~d}$ \\
\hline $\mathrm{C} 2-\mathrm{C} \mathrm{a}$ & $20.30 \mathrm{c}$ & $2.15 \mathrm{~d}$ & $0.14 \mathrm{c}$ & $0.15 \mathrm{c}$ & $0.29 \mathrm{c}$ & $1.12 \mathrm{~b}$ & $0.028 \mathrm{~d}$ \\
\hline C1-B & $23.79 \mathrm{~b}$ & $2.63 \mathrm{c}$ & $0.37 \mathrm{~b}$ & $0.37 \mathrm{~b}$ & $0.74 \mathrm{~b}$ & $1.09 \mathrm{~b}$ & $0.072 \mathrm{~b}$ \\
\hline $\mathrm{C} 1-\mathrm{S}$ & $24.34 \mathrm{~b}$ & $2.65 \mathrm{c}$ & $0.33 \mathrm{~b}$ & $0.35 \mathrm{~b}$ & $0.68 \mathrm{~b}$ & $1.18 \mathrm{~b}$ & $0.069 \mathrm{~b}$ \\
\hline $\mathrm{C} 1-\mathrm{K}$ & $24.83 \mathrm{~b}$ & $2.66 \mathrm{c}$ & $0.36 \mathrm{~b}$ & $0.37 \mathrm{~b}$ & $0.72 \mathrm{~b}$ & $1.08 \mathrm{~b}$ & $0.071 \mathrm{~b}$ \\
\hline C1-Cal & $26.48 \mathrm{~b}$ & $2.43 \mathrm{c}$ & $0.23 \mathrm{~b}$ & $0.20 \mathrm{c}$ & $0.43 \mathrm{~b}$ & $0.87 \mathrm{c}$ & $0.035 \mathrm{c}$ \\
\hline $\mathrm{C} 1$ & $28.88 \mathrm{~b}$ & $2.69 \mathrm{c}$ & $0.36 \mathrm{~b}$ & $0.35 \mathrm{~b}$ & $0.70 \mathrm{~b}$ & $0.96 \mathrm{c}$ & $0.063 \mathrm{~b}$ \\
\hline $\mathrm{C} 1-\mathrm{Zn}$ & $29.76 \mathrm{~b}$ & $2.77 \mathrm{c}$ & $0.43 \mathrm{~b}$ & $0.38 \mathrm{~b}$ & $0.82 \mathrm{~b}$ & $0.96 \mathrm{c}$ & $0.070 \mathrm{~b}$ \\
\hline $\mathrm{C} 2-\mathrm{Mg}$ & $35.79 \mathrm{a}$ & $3.11 \mathrm{~b}$ & $0.69 \mathrm{~b}$ & $0.47 \mathrm{~b}$ & $1.16 \mathrm{~b}$ & $0.72 \mathrm{c}$ & $0.094 \mathrm{~b}$ \\
\hline $\mathrm{C} 2$ & $38.51 \mathrm{a}$ & $3.47 \mathrm{~b}$ & $1.07 \mathrm{a}$ & $0.91 \mathrm{a}$ & $1.98 \mathrm{a}$ & $0.95 \mathrm{c}$ & $0.163 \mathrm{a}$ \\
\hline $\mathrm{C} 1-\mathrm{N}$ & $38.74 \mathrm{a}$ & $3.87 \mathrm{a}$ & $1.54 \mathrm{a}$ & $1.49 \mathrm{a}$ & $3.03 \mathrm{a}$ & $1.06 \mathrm{~b}$ & $0.262 \mathrm{a}$ \\
\hline
\end{tabular}

Complete treatment $\mathrm{C} 2$ was better than complete $\mathrm{C} 1$, showing that the species is particularly demanding in calcium, lower value in treatment with liming shows that the species is tolerant to soils with acid $\mathrm{PH}$, it was also possible to verify that the species is little demanding in magnesium. Bernardino et al. (2007) achieved the best results for this species using correctives with $100 \% \mathrm{CaCO}_{3}$. 

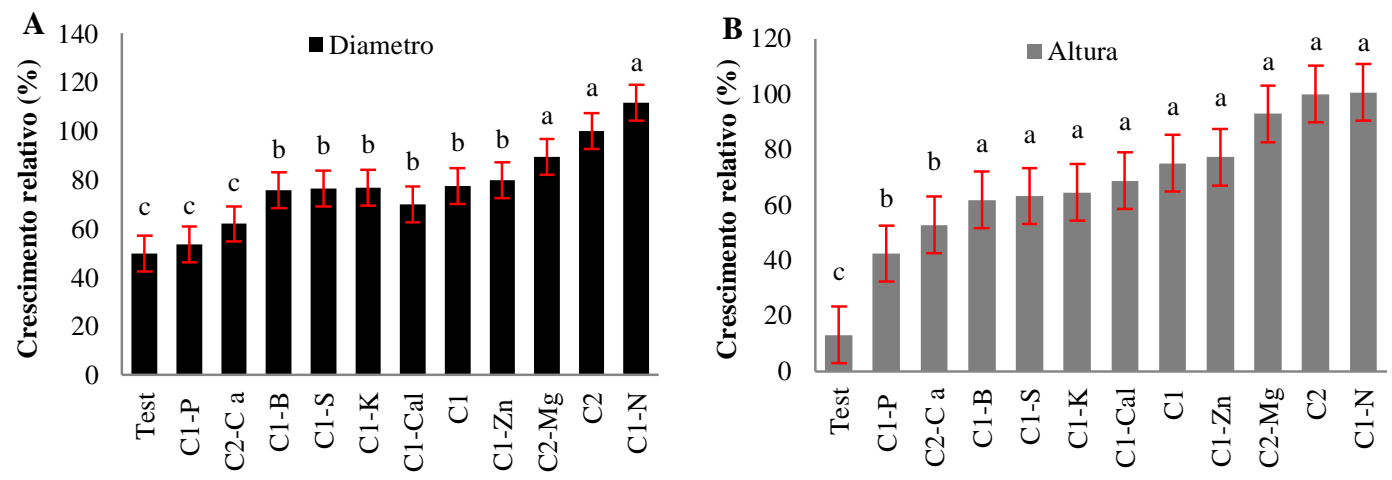

Figure 1. Relative growth (\%) in diameter (A) and height (B) for Dalbergia nigra seedlings, in different treatments, 180 days after transplanting, in Lavras, MG.

Figura 1. Crescimento relativo em diâmetro (A) e altura (B) para mudas de Dalbergia nigra nos diferentes tratamentos, aos 180 dias após transplantio, em Lavras, MG.

The highest values for dry matter and the greatest relative growth in DMAP were found in treatments $\mathrm{C} 1-\mathrm{N}$ and $\mathrm{C} 2$ (Table 3 and Figure 2), and the greatest relative growth in DMRS was obtained in treatments $\mathrm{C} 1-\mathrm{N}$ (Figure 2). Where the nitrogen fertilization was applied, mean values of dry matter were, in general, lower than in treatments without $\mathrm{N}$. These results indicate the tendency to apply inoculation with rhizobia, which provides enough nitrogen to form high quality seedlings. Similar result was observed in Anadenanthera macrocarpa (Benth) Brenan seedlings, where rhizobia inoculation was applied and different mineral nitrogen sources too, and results showed that the greatest growth was where mineral fertilization was not applied. Authors comment that these results may be due to nitrogen sources, affecting nodule formation and development process and probably to ammonium nitrate, which inhibited formation of nodules (CHAVES et al., 2006).

Sequence of nutrients that most influenced growth of D. nigra seedlings compared to complete treatment $\mathrm{C} 1$, considering aerial part dry matter production, in decreasing order, were: $\mathrm{P}>\mathrm{Ca}>\mathrm{S}>\mathrm{K}>\mathrm{B}>\mathrm{Zn}>\mathrm{Mg}>\mathrm{N}$.
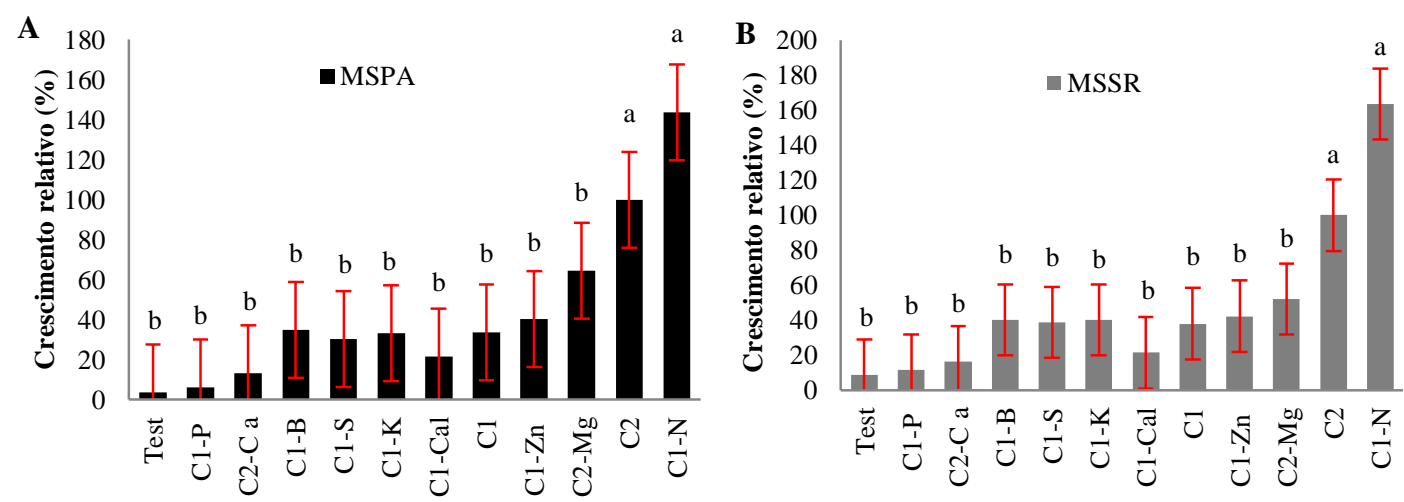

Figure 2. Relative growth (\%) in dry biomass of the aerial part (A) and root system (B) of Dalbergia nigra seedlings, in different treatments, 180 days after transplanting, in Lavras, MG.

Figura 2. Crescimento relativo em matéria seca da parte aérea (MSPA) (A) e sistema radicular (MSSR) (B) para mudas de Dalbergia nigra nos diferentes tratamentos, aos 180 dias após transplantio, em Lavras, MG.

The root/aerial ratio part for Jacarandá-da Bahia (Table 3) shows that this species gives priority to the root system. The greatest R/AP ratio of the control treatments and in treatments without $\mathrm{P}$ probably resulted from the fact that the species invests more in the roots system when in low fertility and low $\mathrm{P}$ availability conditions, looking for more absorption of nutrients from soil, a genetic and evolutionary 
characteristic. Resende et al, (1999), who showed linear growths in biomass and diminution of the root/aerial part ratio with increase of phosphorus contents, comment that they found relatively small quantities of $\mathrm{P}$ in the plants after incubation in soil, explaining this fact with the strong fixation of this element in the used soil, a Dark-Red Latosol, dystrophic and clayey. Phosphorus is the most limiting nutrient to biomass productivity in tropical soils, being the most used for fertilization in Brazil due to natural poorness of soils and the strong interaction of this nutrient with soil (RAIJ, 1991).

The strongest Dickson quality index of seedlings was found in the treatment with omissions. N. Gomes (2001) cited that the bigger is Dickson quality index, the better is the quality standard of seedlings.

\section{Mineral nutrition}

Contents of nutrients in dry matter of aerial part of Jacarandá da Bahia seedlings were low depending on treatments with omission of each nutrient (Table 4). The accumulated quantity (accumulation) of nutrients in the dry matter of the aerial part (DMAP) of Jacarandá da Bahia is presented in table 5.

Table 4. Nutrient content in dry matter of aerial plant of Jacarandá da Bahia seedlings subjected to treatments with and without omission of nutrients 180 days after transplanting.

Tabela 4. Teor de nutrientes na matéria seca da parte aérea de mudas de Jacarandá da Bahia submetidas a tratamentos com e sem omissão de nutrientes, aos 180 dias após transplantio.

\begin{tabular}{|c|c|c|c|c|c|c|c|c|}
\hline Treatments & $\mathbf{N}$ & $\mathbf{P}$ & $\mathbf{K}$ & Ca & Mg & $\mathbf{S}$ & B & Zn \\
\hline & \multicolumn{6}{|c|}{ 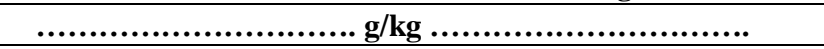 } & \multicolumn{2}{|c|}{.............mg/kg ............ } \\
\hline $\mathrm{C} 1$ & $22 \mathrm{a}$ & $0.79 \mathrm{~b}$ & $9.72 \mathrm{a}$ & $7.91 \mathrm{~b}$ & $3.01 \mathrm{~b}$ & $1.6 \mathrm{a}$ & $41.66 \mathrm{a}$ & $13.52 \mathrm{~b}$ \\
\hline $\mathrm{C} 1-\mathrm{N}$ & $19.58 \mathrm{a}$ & $1.44 \mathrm{a}$ & $10.62 \mathrm{a}$ & $7.68 \mathrm{~b}$ & $4.02 \mathrm{a}$ & $1.47 \mathrm{a}$ & $19.77 \mathrm{c}$ & $17.12 \mathrm{~b}$ \\
\hline $\mathrm{C} 1-\mathrm{P}$ & $10.9 \mathrm{~b}$ & $0.4 \mathrm{~b}$ & $9.19 \mathrm{a}$ & $11.92 \mathrm{a}$ & $1.98 \mathrm{c}$ & $1.81 \mathrm{a}$ & $17.25 \mathrm{c}$ & $29.98 \mathrm{a}$ \\
\hline $\mathrm{C} 1-\mathrm{K}$ & $22.14 \mathrm{a}$ & $1.66 \mathrm{a}$ & $7.92 \mathrm{a}$ & $9.1 \mathrm{~b}$ & $4.09 \mathrm{a}$ & $1.49 \mathrm{a}$ & $20.72 \mathrm{c}$ & $20.28 \mathrm{~b}$ \\
\hline $\mathrm{C} 1$ - Cal & $23.89 \mathrm{a}$ & $0.65 \mathrm{~b}$ & $8.46 \mathrm{a}$ & $8.18 \mathrm{~b}$ & $2.87 \mathrm{~b}$ & $1.52 \mathrm{a}$ & $29.23 \mathrm{~b}$ & $12.22 \mathrm{~b}$ \\
\hline $\mathrm{C} 1-\mathrm{S}$ & $21.89 \mathrm{a}$ & $1.23 \mathrm{a}$ & $9.18 \mathrm{a}$ & $7.85 \mathrm{~b}$ & $2.48 \mathrm{c}$ & $1.55 \mathrm{a}$ & $15.74 \mathrm{c}$ & $13.67 \mathrm{~b}$ \\
\hline $\mathrm{C} 1-\mathrm{B}$ & $26.97 \mathrm{a}$ & $0.71 \mathrm{~b}$ & $7.74 \mathrm{a}$ & $7.7 \mathrm{~b}$ & $3.01 \mathrm{~b}$ & $1.59 \mathrm{a}$ & $17.23 \mathrm{c}$ & $17.67 \mathrm{~b}$ \\
\hline $\mathrm{C} 1-\mathrm{Zn}$ & $30.2 \mathrm{a}$ & $1.52 \mathrm{a}$ & $7.75 \mathrm{a}$ & $10.66 \mathrm{a}$ & $3.61 \mathrm{a}$ & $1.41 \mathrm{a}$ & $23.09 \mathrm{c}$ & $15.33 \mathrm{~b}$ \\
\hline $\mathrm{C} 2$ & $22.21 \mathrm{a}$ & $1.24 \mathrm{a}$ & $10.05 \mathrm{a}$ & $7.2 \mathrm{~b}$ & $2.73 \mathrm{~b}$ & $1.69 \mathrm{a}$ & $22.44 \mathrm{c}$ & $15.7 \mathrm{~b}$ \\
\hline $\mathrm{C} 2-\mathrm{Mg}$ & $26.94 \mathrm{a}$ & $1.1 \mathrm{a}$ & $9.25 \mathrm{a}$ & $9.99 \mathrm{a}$ & $2.76 \mathrm{~b}$ & $1.31 \mathrm{a}$ & $22.03 \mathrm{c}$ & $17.2 \mathrm{~b}$ \\
\hline $\mathrm{C} 2-\mathrm{Ca}$ & $22.23 \mathrm{a}$ & $1.44 \mathrm{a}$ & $8.34 \mathrm{a}$ & $9.44 \mathrm{a}$ & $3.14 \mathrm{~b}$ & $1.42 \mathrm{a}$ & $16.99 \mathrm{c}$ & $15.3 \mathrm{~b}$ \\
\hline Test & $25.43 \mathrm{a}$ & $1.01 \mathrm{a}$ & $8.24 \mathrm{a}$ & $10.64 \mathrm{a}$ & $3.2 \mathrm{~b}$ & $1.69 \mathrm{a}$ & $20.5 \mathrm{c}$ & $15,75 \mathrm{~b}$ \\
\hline
\end{tabular}

* Different letters in the column indicate difference between variables by the Scott-Knott test at $5 \%$ of significance.

Table 5. Nutrient accumulation in dry matter of aerial plant (DMAP) of Jacarandá da Bahia seedlings subjected to treatments with and without omission of nutrients 180 days after transplanting.

Tabela 5. Acúmulo de nutrientes na matéria seca da parte aérea (MSPA) de mudas de Jacarandá da Bahia submetidas a tratamentos com e sem omissão de nutrientes aos 180 dias após transplantio.

\begin{tabular}{|c|c|c|c|c|c|c|c|c|}
\hline Treatments & $\mathbf{N}$ & $\mathbf{P}$ & $\mathbf{K}$ & $\mathbf{C a}$ & Mg & $\mathbf{S}$ & B & Zn \\
\hline \multicolumn{9}{|c|}{ 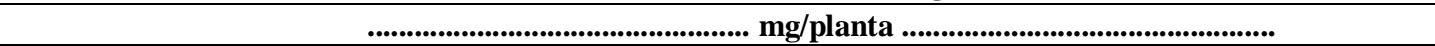 } \\
\hline $\mathrm{C} 1$ & $7.92 \mathrm{c}$ & $0.28 \mathrm{~d}$ & $3.50 \mathrm{~d}$ & $2.85 \mathrm{~d}$ & $1.08 \mathrm{~b}$ & $0.58 \mathrm{~d}$ & $0.015 \mathrm{c}$ & $0.005 \mathrm{e}$ \\
\hline $\mathrm{C} 1-\mathrm{N}$ & $30.15 \mathrm{a}$ & $2.27 \mathrm{a}$ & $16.35 \mathrm{a}$ & $11.83 \mathrm{a}$ & $6.19 \mathrm{a}$ & $2.26 \mathrm{a}$ & $0.030 \mathrm{a}$ & $0.026 \mathrm{a}$ \\
\hline $\mathrm{C} 1-\mathrm{P}$ & $0.61 \mathrm{~d}$ & $0.02 \mathrm{e}$ & $0.55 \mathrm{f}$ & $0.72 \mathrm{e}$ & $0.12 \mathrm{c}$ & $0.11 \mathrm{f}$ & $0.001 \mathrm{f}$ & $0.002 \mathrm{f}$ \\
\hline $\mathrm{C} 1-\mathrm{K}$ & $7.97 \mathrm{c}$ & $0.60 \mathrm{c}$ & $2.85 \mathrm{~d}$ & $3.28 \mathrm{~d}$ & $1.47 \mathrm{~b}$ & $0.54 \mathrm{~d}$ & $0.007 \mathrm{e}$ & $0.007 \mathrm{~d}$ \\
\hline C1 - Cal & $5.49 \mathrm{c}$ & $0.15 \mathrm{e}$ & $1.95 \mathrm{e}$ & $1.88 \mathrm{e}$ & $0.66 \mathrm{~b}$ & $0.35 \mathrm{e}$ & $0.007 \mathrm{e}$ & $0.003 \mathrm{f}$ \\
\hline $\mathrm{C} 1-\mathrm{S}$ & $7.22 \mathrm{c}$ & $0.41 \mathrm{~d}$ & $3.03 \mathrm{~d}$ & $2.59 \mathrm{~d}$ & $0.82 \mathrm{~b}$ & $0.51 \mathrm{~d}$ & $0.005 \mathrm{e}$ & $0.005 \mathrm{e}$ \\
\hline C1 - B & $9.98 \mathrm{c}$ & $0.26 \mathrm{~d}$ & $2.86 \mathrm{~d}$ & $2.85 \mathrm{~d}$ & $1.11 \mathrm{~b}$ & $0.59 \mathrm{~d}$ & $0.006 \mathrm{c}$ & $0.007 \mathrm{~d}$ \\
\hline $\mathrm{C} 1-\mathrm{Zn}$ & $12.89 \mathrm{c}$ & $0.65 \mathrm{c}$ & $3.33 \mathrm{~d}$ & $4.58 \mathrm{c}$ & $1.55 \mathrm{~b}$ & $0.61 \mathrm{~d}$ & $0.010 \mathrm{~d}$ & $0.007 \mathrm{~d}$ \\
\hline $\mathrm{C} 2$ & $23.76 \mathrm{~b}$ & $1.32 \mathrm{~b}$ & $10.75 \mathrm{~b}$ & $7.70 \mathrm{~b}$ & $2.92 \mathrm{~b}$ & $1.81 \mathrm{~b}$ & $0.024 \mathrm{~b}$ & $0.017 \mathrm{~b}$ \\
\hline $\mathrm{C} 2-\mathrm{Mg}$ & $18.59 \mathrm{~b}$ & $0.76 \mathrm{c}$ & $6.38 \mathrm{c}$ & $6.89 \mathrm{~b}$ & $1.90 \mathrm{~b}$ & $0.90 \mathrm{c}$ & $0.015 \mathrm{c}$ & $0.012 \mathrm{c}$ \\
\hline $\mathrm{C} 2-\mathrm{Ca}$ & $3.11 \mathrm{~d}$ & $0.21 \mathrm{~d}$ & $1.17 \mathrm{f}$ & $1.32 \mathrm{e}$ & $0.44 \mathrm{c}$ & $0.2 \mathrm{f}$ & $0.002 \mathrm{~d}$ & $0.002 \mathrm{f}$ \\
\hline Test & $1.01 \mathrm{~d}$ & $0.04 \mathrm{e}$ & $0.33 \mathrm{f}$ & $0.43 \mathrm{e}$ & $0.13 \mathrm{c}$ & $0.07 \mathrm{f}$ & $0.001 \mathrm{f}$ & $0.001 \mathrm{f}$ \\
\hline
\end{tabular}

FLORESTA, Curitiba, PR, v. 45, n. 1, p. 107 - 116, jan. / mar. 2015.

Carlos, L. et al.

ISSN eletrônico 1982-4688 / ISSN impresso 0015-3826 
With the exception of treatment without phosphorus, which had smaller $\mathrm{N}$ content, all the other treatments were similar. These contents are bigger than what Moretti et al. (2011) found. These high values even with omission of $\mathrm{N}$ application are related to the fact that the plant performs symbiosis with rhizobia in soil.

The greatest $\mathrm{N}$ accumulation occurred in the treatment $\mathrm{C} 1-\mathrm{N}$, this effect happened to the bigger DMAP resulted in this treatment. The lowest accumulations are found in control, $\mathrm{C} 1-\mathrm{P}$ and $\mathrm{C} 1-\mathrm{Ca}$ treatments, results aligned with DMAP. Contents and accumulations are bigger than what found by Moretti et al. (2011). The high values of accumulation, even in absence of nitrogen application, are due to the fact that this species performs symbioses with rhizobia in soil, presenting bigger growth and consequently greater accumulation of nutrients in the DMAP.

The lowest contents in phosphorous were found in treatments where there was its omission, and where there was omission of boron and liming, like in complete treatment 1 . The lowest accumulations of phosphorous were found in treatments with its omission, in liming omission and in control. Absence of liming diminishes $\mathrm{P}$ availability in soil, since increases its fixation in soil, thus reducing content in tissues and consequently the accumulated content (LOPES et al., 1990). In mineral nutrition of plants, phosphorous stands out for its importance in plant metabolism, being present in various biochemical activities, being part of DNA, RNA and ATP, among others (EPSTEIN; BLOOM, 2004), since its lack influences development of plants.

Contents of $\mathrm{K}$ in tissues were the same for all treatments (Table 4), thus $\mathrm{K}$ accumulations (Table 5) depended on DMAP. Therefore, the greatest accumulation was found in C1-N treatment, and the smallest accumulations were found in control treatments and with absence of phosphorous and calcium, in other words, tissue absorbed similar contents in each treatment, differing only in terms of relative growth. This indicates that this species is little demanding in potassium, being thus efficient to grow and absorb nutrients in in soil conditions similar to the ones presented in this work (Table 2). In other words, with $23 \mathrm{mg}$ of potassium per $\mathrm{dm}^{3}$ of soil, these results were found by Venturin et al., (2005), studying Candeia, which is another little demanding species.

The greatest accumulation of Ca were found in DMAP of the treatment with omission of N, once this gave the greatest dry mass. Smallest accumulations were found in treatments with absence of calcium and liming, like in omission of phosphorous and control.

Treatment with absence of nitrogen was the one that presented the biggest Mg accumulations, due to the bigger quantity of dry matter of the aerial part given by the treatment. The treatment with omission of potassium obtained high content of $\mathrm{Mg}$ in the DMAP, possibly due to reduction of antagonism between potassium and Mg (MALAVOLTA et al., 1997).

Sulfur contents in DMAP of Jacarandá da Bahia were equal for all treatments. Results for accumulation were similar to DMAP growth, being the treatment with omission of nitrogen the one that presented greatest accumulation, while control, $\mathrm{P}$ and $\mathrm{Ca}$ absence presented the lowest accumulations. This shows that quantity of sulfur in soil was enough to satisfy plant necessities. Values are similar to what found by Souza et al. (2009) in complete treatments for Cedar.

The greatest $\mathrm{B}$ contents were found in complete treatment 1 . The biggest accumulation of boron was found in treatment with absence of $\mathrm{N}$, the smallest contents were found in control and absence of $\mathrm{P}$.

$\mathrm{Zn}$ accumulation in the plant happened in similar way in the various treatments. Absence of $\mathrm{N}$ favored the greatest accumulation and the smallest accumulations resulted from control treatments, $\mathrm{P}, \mathrm{Ca}$ and liming absence. Treatment with $\mathrm{P}$ omission was the one that presented greatest $\mathrm{Zn}$ contents in dry matter of the aerial part. The great content of $\mathrm{Zn}$ in absence of $\mathrm{P}$ is due to reduction of non-competitive inhibition between ions $\mathrm{Zn}^{2+}$ and $\mathrm{H}_{2} \mathrm{PO}_{4}{ }^{-}$(MALAVOLTA et al., 1997).

\section{CONCLUSIONS}

Results obtained under the condition of this research allowed the following conclusions:

- Phosphorous is the most limiting nutrient to growth of Jacarandá da Bahia.

- The sequence of nutrients that most had influence on D. nigra plants growth compared to the complete treatment, considering dry matter of the aerial part, were, in decreasing order: $\mathrm{P}>\mathrm{Ca}>\mathrm{S}>$ $\mathrm{K}>\mathrm{B}>\mathrm{Zn}>\mathrm{Mg}>\mathrm{N}$. 


\section{REFERENCES}

ALVAREZ, V. V. H. Equilíbrio de formas disponíveis de fósforo e enxofre em dois Latossolos de Minas Gerais, 1974. 125 f. Dissertação (Mestrado em Solos e Nutrição de Plantas) - Universidade Federal de Viçosa, Viçosa, MG, 1974.

BERNARDINO, D. C. S.; PAIVA, H. N.; NEVES, J. C. L.; GOMES, J. M.; MARQUES, V. B. Influência da Saturação por bases e da relação Ca:Mg do substrato sobre o crescimento inicial de jacarandá da Bahia (Dalbergia nigra) Vell. FR. All. Ex Benth). Revista Árvore, Viçosa, v. 31, n. 4, p. $567-573,2007$.

BRAGA, F. A.; VALE, F. R.; VENTORIN, N.; AUBERT, E.; LOPES, G. A. Requerimentos nutricionais de quatro espécies florestais Revista Árvore, Viçosa, v. 19, n. 1, p. 18 - 32, 1995.

CARLOS, L.; VENTURIN, N.; HIGASHIKAWA, E. M.; SANTOS, S. C.; MACEDO, R. L. G. Crescimento e nutrição mineral de mudas de óleo-bálsamo sob o efeito de omissão de nutrientes. Enciclopédia Biosfera, Goiânia, v. 9, n. 17, p. 894 - 904, 2013.

CARVALHO, P. E. R. Mimosa scabrella Bentham var. aspericarpa (hoehne) Burkart. In: Carvalho, P.E R. Espécies florestais brasileiras: recomendações silvicultuais, potencialidades e uso da madeira. Colombo: EMBRAPA-CNPF / Brasília: EMBRAPA SPI, p. 344 - 347, 1994.

CHAMINADE, R. Recherches sur la fertilité et la fertilisation des sols en régions tropicales. Agronomie Tropicale, Montpellier, v. 27, n. 9, p. 891 - 904, 1972.

CHAVES, L. L. B.; CARNEIRO, J. G. A.; BARROSO, D. G. Crescimento de mudas de Anadenanthera macrocarpa (Benth) Brenan (Angico-vermelho) em substrato fertilizado e inoculado com rizóbio. Revista Árvore, Viçosa, v. 30, n. 6, p. 911 - 919, 2006.

DICKSON, A.; LEAF, A.; HOSNER, J. F. Quality appraisal of white spruce and white pine seedling stock in nurseries. Forestry Chronicle, Mattawa, v. 36, n. 1, p. 10 - 13, 1960.

EMPRESA BRASILEIRA DE PESQUISA AGROPECUÁRIA (EMBRAPA). Manual de métodos de análise de solos. 2. ed. Rio de Janeiro: CNPS, 1997. 212 p.

EPSTEIN, E.; BLOOM, A. J. Nutrição mineral de plantas: princípios e perspectivas. 2.ed. Londrina: Planta, 2004. 403 p.

FERREIRA, D. F. Sisvar: a computer statistical analysis system. Ciência e Agrotecnologia, Lavras, v. 35, n. 6, p. 1039 - 1042, 2011.

FREIRE, J. C.; RIBEIRO, M. A. V.; BAHIA, V. G.; LOPES, A. S.; MOVAIS, R. F. Métodos de aplicação de adubos na formação de mudas de Eucalyptus grandis F. Hill ex Maiden. Silvicultura, São Paulo, v. 14, p. 385 - 386, 1979.

GOMES, F. P. Curso de estatística experimental. 2.ed. São Paulo: Nobel, 1985. 466 p.

GOMES, J. M. Parâmetros morfológicos na avaliação da qualidade de mudas de Eucaliptus grandis, produzidas em diferentes tamanhos de tubetes e de dosagens de NPK. $126 \mathrm{f}$. Tese (Doutorado em Ciência Florestal)-Universidade Federal de Viçosa, Viçosa, MG, 2001.

INSTITUTO BRASILEIRO DO MEIO AMBIENTE E DOS RECUROS NATURAIS RENOVÁVEIS (IBAMA). Portaria Normativa $\mathbf{N}^{\mathbf{0}}$. 37, de 3 de abril de 1992. Torna pública a lista oficial de espécies da flora brasileira ameaçada de extinção. Brasília: Diário Oficial da União, de 03 de Abril de 1992.

JACKSON, M. L. Análise química de suelos. Barcelona: Omega, 1970. 66 p.

LOPES, A. S.; SILVA, M. C.; GUILHERME, L. R. G. Acidez do solo e calagem. 3a ed. - São Paulo: ANDA, 1990. 22 p.

LORENZI, H. Árvores brasileiras: manual de identificação e cultivo de plantas arbóreas nativas do Brasil. Nova Odessa: Plantarum, 2002. 368 p. 
MALAVOLTA, E. Elementos de nutrição mineral de plantas. São Paulo: Ceres, 1980. 251 p.

MALAVOLTA, E. Manual de nutrição mineral de plantas. São Paulo: Ceres, 2006. 638 p.

MALAVOlTA, E.; VITTI, G. C.; OLIVEIRA, S. A. Avaliação do estado nutricional das plantas: princípios e aplicações. 2.ed. Piracicaba: POTAFOS, 1997. 319 p.

MARQUES, V. B.; PAIVA, H. N.; GOMES, J. M.; NEVES, J. C. L.; BERNARDINO, D. C. S. Efeito de fontes de nitrogênio sobre o crescimento inicial e qualidade de mudas de Jacarandá da Bahia (Dalbergia nigra (Vell) Fr. All. ex Benth). Revista Árvore, Viçosa - MG, n. 15, p. 725 - 735, 2006.

MORETTI, B. S.; FURTINI NETO, A. E.; PINTO, S. I. C.; FURTINI, I. V.; MAGALHÃES, C. A. S. Crescimento e nutrição mineral de cedro australiano (Toona ciliata) sob omissão de nutrientes. Cerne, Lavras, v. 17, n. 4, p. 453 - 463, 2011.

MYERS, N.; MITTERMEIER, R. A.; MITTERMEIER, C. G.; FONSECA, G. A. B.; KENT, J. Biodiversity hotspots for conservation priorities. Nature, v. 403, p. 853 - 858, 2000.

PASSOS, M. A. A. Efeito da calagem e de fósforo no crescimento inicial da algaroba (Prosopis juliflora (SW) DC). 1994. 57 f. Tese (Doutorado em Fitotecnia) - Universidade Federal de Viçosa, Viçosa, MG, 1994.

PRITCHETT, W. L. Propriets and manegement of forest soils. New York: J.Wiley, 1979. 500 p.

RAIJ, B. V. Avaliação da Fertilidade do solo. Piracicaba, Associação Brasileira para pesquisa da Potassa e do Fosfato, 1981. 142 p.

RAIJ, B. V. Fertilidade do solo e adubação. São Paulo: Associação Brasileira para Pesquisa da Potassa e do Fosfato/Agronômica Ceres, 1991. 343 p.

RESENDE, A. V.; FURTINI NETO, A. E.; MUNIZ, J. A.; CURI, N.; FAQUIN, V. Crescimento inicial de espécies florestais de diferentes grupos sucessionais em resposta a doses de fósforo. Pesq. Agrop. Bras. v. 34, n. 11, p. 2071 - 2081, 1999.

RIBEIRO, R. A.; LEMOS-FILHO, J. P.; RAMOS, A. C. S.; LOVATO, M. B. Phylogeography of the endangered rosewood Dalbergia nigra (Fabaceae): insights into the evolutionary history and conservation of the Brazilian Atlantic Forest. Heredity, Bethesda, v. 106, n. 1, p. 46 - 57, 2011.

SARRUGE, J. R.; HAAG, H. P. Análises químicas em plantas. Piracicaba: ESALQ/USP, 1974. 56 p.

SOUZA, P. A.; VENTURIN, N.; MACEDO, R. L. G.; VENTURIN, R. P.; TUCCI, C. A. F.; CARLOS, L. Nutritional assessment of cedar seedlings (cedrela fissilis vell.)grown in a greenhouse. Cerne, Lavras, v. 15, n. 2, p. 236 - 243, 2009.

TEDESCO, M. J.; VOLKWEISS, S. J.; BOHNRN, H. Análise do solo, plantas e outros materiais. Porto Alegre: UFRGS, 1985. 188 p.

VENTURIN, N.; SOUZA, P. A.; MACEDO, R. L. G.; NOGUEIRA, F. D. Adubação mineral da candeia (Eremanhus erythropappus (DC.) McLeish). Floresta, Curitiba, v. 35, n. 2, p. 211 - 219, 2005.

VETTORI, L. Métodos de análise de solo. Rio de Janeiro: Ministério da Agricultura, 1969. 34 p.

VIETS JUNIOR, F. G. e; LINDSAY, W. L. Testing soils for zinc, Cooper, manganese and iron. In: WALSH, L. M.; BEATON, J. D. (Ed.). Soil testing and plant analylis. Madison: Soil Science society of America, p. 329 - 488. 1973.

WALKLEY, A.; BLACK, I. A. An examination of the Degtjareff method for determining soil organic matter, and a proposed modification of the chromic acid titration method. Soil Science, Baltimore, v. 37, p. $29-38,1934$. 